\title{
Using Movies in Efl Classrooms
}

Ramazan Goctu

\begin{abstract}
This research examines the attitudes and awareness of foreign language (EFL) learners to the integration of English movies in their classes in terms improving their foreign language skills. 25 intermediate level students studying English in Faculty of Education and Humanities in Philology Department at International Black Sea University, Tbilisi, Georgia, participated in this study. Students watched the movies at home and films were analyzed at the lectures. After analyzing the films, 7 various questions were asked to students in order to obtain their awareness towards the using films in ELT classrooms. The findings of the study indicated that students have positive attitudes towards the use of movies in their classes in terms of improving their language skills. Until quite recently, it was difficult to find pedagogically sound film material to help students improve their language through watching film, and teachers had to spend many hours creating their own materials. However, with the advent of the internet there is now a wealth of online resources for both language teachers and their students. This study is remarkable for teachers who are willing to use movies in their classes as a tool to improve their learners' foreign language level.
\end{abstract}

Key Words: Movies, EFL, awareness, implication, motivation.

\section{Introduction}

Movies are an invaluable way for students to practice and listen authentic conversations and be exposed to different accents. EFL teachers can use countless movies to introduce discussions about a certain topic, a historical event, a time period or the culture of a foreign country. Bringing popular movies into EFL lessons, shows students how they can learn and practice English when watching movies in their own time. Films in video format should not be regarded as only a secondary in a listening class; on the contrary, they can function as the main content and become an integral part of the curriculum (Sommer, 2001). In listening classes, having traditional listening excerpts is not as effective and beneficial as authentic materials like movies, TV serials, short film trailers and some other authentic videos. Course books and CDs offered in English classes turn out to be artificial and not very pleasing for students. One way of bringing variety into the classroom is the use of movies in EFL teaching. This paper analyzes the effects of using movies in the EFL classroom. It reveals its effects on developing students listening and communication skill.

\section{Literature Review}

Movies attract students' attention, present language in a more natural way that found in course-books. Movies also offer a visual context aid which helps students understanding and in order to improve their learning skills. Nowadays teaching English has become more challenging than ever. In order to help the learners' mastery (enhance the proficiency) of language skills, language teachers have to provide quality teaching materials that will be engaging, interesting, up-to-date while simultaneously being a tool that will ensure that the students learn. There are numerous studies on the use of videos in developing particular language skills, especially listening comprehension (Gruba, 2006 ; Suvorov, 2008).

According to (Ismaili, 2013) movies are an enjoyable source of entertainment and language acquisition. For this reason, many researchers and EFL practitioners prefer to watch the movie adaptations of famous and current novels as a supplementary source to the reading. Practice has shown that reading an entire book can be tiresome and boring while an audio-visual experience can be more entertaining and engaging to students.

As King (2002) indicates in his work, movies are such invaluable and rich resources for teaching because they present colloquial English in real life contexts rather than artificial situations; a chance of being exposed to different native speaker voices, stress, accents, and dialects.

Listening is the predominant skill among other integrated skills in presenting movies in EFL classes whether the movies chosen are presented with subtitles or not. Hence movies can provide an opportunity for extensive listening, "listening for 
general pleasure or interest, usually to longer stretches of discourse" (Flowerdew, J. Miller, L., 2005). However, to make the practice of listening tasks more useful, the movies may be presented without subtitles depending on the learners' language proficiency level.

Findings from previous studies provide support for students wanting to have more video materials (i.e., video clips) embedded in their classroom (B. Goldstein,P.Driver, 2014).

Different types of video material are easily accessible with mobile devices or smart phones via internet and teachers can pick up from a rather varied set of materials depending on the learner's age and language proficiency.

Movies are being used for pedagogical purposes in order to motivate language learners and they are easily available and popular entertainment form of teaching tool in English teaching as a foreign language, for students particularly in recent years. Based on this idea, the present paper attempts to explore some learning activities designed to improve EFL learners' active listening skill as well as other integrated skills. It is assumed that the language spoken in the movies, but also presented in the proper cultural context can be a valuable by means of increasing more appropriate use of language (Chapple, L. \& Curtis, A., 2000).

\section{Methodology}

In this study, 5-point Likert Scale questionnaire was implemented in order to find out what extent the students believed watching movies could help them to improve their language skills and their awareness the integration of movies in their classrooms.

\section{Participants}

The participants in the study were 25 upper-intermediate level students studying English in International Black Sea University, Faculty of Educations and Humanities, Philology Department. The participants' ages between 19 and 21 years old. Students were from different nationalities; Georgian, Turkish, Azerbaijani.

\section{Procedure}

Students in the present study sacrificed thirty minutes of their four-hour English class to do the movie activity over a period of six weeks. They watched four movies during that period. Movies were chosen by the researcher. Names of the films are: Cast Away (Zemeckis, 2000), The Pursuit of Happiness (Muccino, 2006) Akeelah and the Bee (Atchison, 2006), Paper Planes (Connolly, 2014). Students watched the films at home, however, the watched movies were analyzed at the classroom. In order to reach the optimum implications, films were analyzed in terms of three various aspects, literary aspects, cultural aspects and language aspects. Following steps were implemented during the course:

\section{Literary Aspects}

- Who are the characters in the film?

- What is the film's setting?

- What are the main plot elements?

- What is the theme of the film?

\section{Cultural Aspects}

- Cultural quotations and conversations

- The socio-historical background of the film

- The ideology, the trends and characteristics of the society at the time of the production

\section{Language Aspects}

- $\quad$ Language of the film (how the forms of communication are used in the film)

- $\quad$ Memorable quotes in the film; metaphors, symbols, ellipsis, contrast etc.

- $\quad$ Use of the setting in communication 


\section{Questionnaire}

After analyzing of 4 aforementioned films, 7 different questions were asked to students in order to obtain their awareness towards the using films in EFL classrooms.

\section{Table 1. Survey Questions}

\begin{tabular}{|l|l|l|l|l|l|l|}
\hline No & Questions & $\begin{array}{l}\text { Strongly } \\
\text { Agree }\end{array}$ & Agree & Neutral & Disagree & $\begin{array}{l}\text { Strongly } \\
\text { Disagree }\end{array}$ \\
\hline 1 & $\begin{array}{l}\text { Do you think watching movies in the } \\
\text { classroom makes it easier for you to learn } \\
\text { English? }\end{array}$ & $36 \%$ & $52 \%$ & $12 \%$ & 0 & 0 \\
\hline 2 & $\begin{array}{l}\text { Are you interested in learning English and } \\
\text { participating in classroom discussions if the } \\
\text { teacher uses movies as teaching materials? }\end{array}$ & $76 \%$ & $24 \%$ & 0 & 0 & 0 \\
\hline 3 & $\begin{array}{l}\text { Do you think watching movies in English has } \\
\text { a beneficial effect on improving your English } \\
\text { language skills? }\end{array}$ & $80 \%$ & $20 \%$ & 0 & 0 & 0 \\
\hline 4 & $\begin{array}{l}\text { Do you agree that watching movies motivates } \\
\text { you to learn English? }\end{array}$ & $32 \%$ & $28 \%$ & $36 \%$ & $\% 4$ & 0 \\
\hline 5 & $\begin{array}{l}\text { Do you agree that watching movies help you } \\
\text { to comprehend listening activities better? }\end{array}$ & $44 \%$ & $56 \%$ & & & \\
\hline 6 & $\begin{array}{l}\text { The integration of movies in the EFL } \\
\text { classroom decreases your anxiety in } \\
\text { language learning? }\end{array}$ & $12 \%$ & $32 \%$ & $32 \%$ & $16 \%$ & $8 \%$ \\
\hline 7 & $\begin{array}{l}\text { Do you agree that movies can help in } \\
\text { improving your vocabulary acquisition? }\end{array}$ & $48 \%$ & $36 \%$ & $12 \%$ & $4 \%$ & \\
\hline
\end{tabular}

\section{Results of the Survey}

The responses given by the students displayed on an overall level that; students considered the integration of movies in the classroom as effective and beneficial in terms of learning foreign language. Thirty-six percent of the students strongly agreed and more than half of the participants agreed that movies in English could facilitate the learning of English language. Seventy-six percent of the participants strongly agreed that they are more motivated and interested in learning English if their teachers use movies in the classrooms. The majority of the participants found movies to be useful in developing their language skills as well as keep them engaged. Approximately fifty percent of the students agreed to the statement that, the use of movies in their lessons reduce their anxiety in learning English. Eighty percent of them also agreed that movies can help improve their vocabulary acquisition. All participants either strongly agree or agree that, watching movies help them to comprehend listening activities better.

In general, students' responses indicated that the advantages of using movies to teach productive and receptive skills, increased learning interests and motivation. From the students' responses to the questions concerning the development of all skills in the questionnaires revealed that students have positive approach toward this method.

\section{Conclusions}

Using films in the classroom can provide opportunities for learners to evaluate the very medium that they use in their daily life. Films comprises authentic daily conversations also present parts of real life, and as such, they add fun and involvement to the language classroom. The results of the present study indicated that movies are important tools that can help in developing students' language skills. The participants in the study have positive attitudes towards the integration of movies in their classrooms in order to improve their English. The study also showed that using movies in EFL classroom could enhance the students' motivation to learn the language. They also considered that films are helpful for them to improve their vocabulary acquisition not only the words but also variety of vocabulary and colloquial expressions, phrasal verbs, verb phrases. It is worth to note that, selecting appropriate movies for learners is also one of the remarkable factors in terms of reaching the expected objectives. The research confirmed that using movies in English teaching with appropriately 
designed activities and tasks were not only a valuable for the EFL learners, but also, they enhance students' self-motivation, and provided an enjoyable, educational experience for students.

\section{References}

[1] Atchison, D. (Director). ( 2006). Akeelah and the bee [Motion Picture].

[2] B. Goldstein,P.Driver. (2014). Language learning with digital video. CAMBRIDGE: Cambridge University Press.

[3] Chapple, L. \& Curtis, A. (2000). Content-Based Instruction in Hong Kong. Student Responses to Film, 419-433.

[4] Flowerdew, J. Miller, L. (2005). Second Language Listening: Theory and Practice. Cambridge: Cambridge University Press.

[5] Gruba, P. (2006). Playing the videotext: A media literacy perspective on video-mediated L2 listening. Language learning and Technology , 77-92.

[6] Ismaili, M. (2013). The Effectiveness of Using Movies in the EFL Classroom -A Study Conducted at South East European University. Academic Journal of Interdisciplinary Studies, 121-132.

[7] King, J. (2002). Using DVD Feature Films in the EFL Classroom, The Weekly Column. Article 88. Retrieved from http: www.eltnewsletter.com/January 2017.

[8] Muccino, G. (Director). (2006). The Pursuit of Happiness [Motion Picture].

[9] Sommer, P. (2001). Using Film in the English Classroom: Why and How. Journal of Adolescent and Adult Literacy, 485-487.

[10] Suvorov, R. (2008). Context visuals in L2 listening text. The effectiveness of photographs and videos vs. audio-only format. lowa : lowa State University,.

[11] Zemeckis, R. (Director). (2000). Cast Away [Motion Picture]. 